\title{
Extracellular Alkaline Lipase from a Novel Fungus Curvularia sp. DHE 5: Optimisation of Physicochemical Parameters, Partial Purification and Characterisation
}

\author{
Dina Helmy El-Ghonemy ${ }^{1 *}$, Mamdouh S. El-Gamal ${ }^{2}$, Amir Elsayed Tantawy ${ }^{1}$ \\ and Thanaa Hamed Ali ${ }^{1}$ \\ ${ }^{1}$ Department of Microbial Chemistry, Genetic Engineering and Biotechnology Division, \\ National Research Centre, 33 El Buhouth St., EG-12 622 Giza, Egypt \\ ${ }^{2}$ Botany and Microbiology Department, Faculty of Science, Al-Azhar University, EG-11 884 Nasr City, Egypt \\ Received: August 18, 2016 \\ Accepted: April 4, 2017
}

\begin{abstract}
Summary
Thirty isolated fungal strains were screened for lipase production using Phenol Red plates, containing tributyrin as lipidic substrate, and a novel fungus identified genetically as Curvularia sp. DHE 5 was found as the most prominent strain. Various agro-industrial substrates were evaluated as inert supports for lipase production in solid-state fermentation. The highest yield of lipase $((83.4 \pm 2.2) \mathrm{U} / \mathrm{g}$ on dry mass basis) was reported with wheat bran medium after seven days of fermentation at $\mathrm{pH}=7.0$, temperature of $30{ }^{\circ} \mathrm{C}, 70 \%$ moisture content, inoculum size of $1.27 \cdot 10^{7}$ spore/mL and $2 \%$ olive oil as an inducer. Supplementation of the medium with $0.05 \% \mathrm{KCl}$ as an ion source further increased lipase production to $(88.9 \pm 1.2) \mathrm{U} / \mathrm{g}$ on dry mass basis. The enzyme was partially purified through ammonium sulphate fractionation ( $40 \%$ ) followed by dialysis, and its optimum $\mathrm{pH}$ and temperature were reported at 8.0 and $50{ }^{\circ} \mathrm{C}$, respectively, with remarkable $\mathrm{pH}$ and thermal stability.
\end{abstract}

Key words: lipase, Curvularia sp. DHE 5, optimisation of culture conditions, agro-industrial residues, lipase characterisation

\section{Introduction}

Lipases (EC 3.1.1.3) catalyse the hydrolysis of acyl glycerol to glycerol, mono- and diacylglycerol. In addition, they catalyse under certain conditions the synthesis of esters through transesterification, thioesterification and aminolysis (1). Consequently, lipases find application in different industrial sectors, i.e. synthesis of biosurfactants, detergent formulations, oleochemical and agrochemical industries, paper manufacturing and pharmaceutical processing (2). Lipases occur widely in nature and their presence has been reported in several plants, animals and microorganisms (including bacteria, fungi, yeasts and actinomyc- etes). However, microbial lipases occupy a prominent place among other biocatalysts due to their high stability towards extremes of temperature, $\mathrm{pH}$, organic solvents and enantioselectivity (3). Fungal lipases are generally preferred for industrial application because they are usually secreted extracellularly, which enables simple extraction from the fermentation medium. Among major fungal species capable of producing high levels of lipase are Fusarium solani (4), Rhizopus oligosporus (5) and Trichoderma harzianum (6).

Microbial lipases are produced by both submerged fermentation (SmF) and solid-state fermentation (SSF) (7). 
However, SSF is preferred because of its higher yields, lower water output and less energy requirement $(8,9)$. Filamentous fungi are considered as the most adapted microorganism for SSF because of their ability to grow on solid substrates as well as their great tolerance to high osmotic pressure (10). Hence, there is an ongoing interest in isolation and characterisation of novel fungal strains that produce lipolytic enzymes with novel properties well suited for industrial applications. Therefore, the target of this research was to evaluate the potential of a novel locally isolated fungal strain identified morphologically and genetically as Curvularia sp. DHE 5 for alkaline lipase production in SSF. Optimisation of the culture conditions was also investigated for maximum enzyme production in SSF. In addition, partial purification and characterisation of the enzyme were carried out for possible industrial applications.

\section{Materials and Methods}

\section{Materials}

Tributyrin, Triton X-100, Tween 80 and gum arabic were obtained from Acros Chemical Co., Geel, Belgium. $p$-Nitrophenylpalmitate and Tris-(hydroxymethyl)-aminomethane were purchased from Sigma-Aldrich (St. Louis, MO, USA). Potato dextrose agar medium was purchased from Laboratorios Conda S.A., Madrid, Spain. Wheat bran, wheat germ, sunflower oil cake and safflower oil cake were kindly donated from Arma Food Industries, Cairo, Egypt. Cotton seed waste was kindly donated from Mohamed Abbas cotton seed mill factory, As Sinbillawain, El Dakahleya, Egypt. Jojoba oil cake was kindly donated from Lana Cosmetics Co., Cairo, Egypt. Rice straw, rice husk and rice bran were kindly donated from Alfyoum Co., Cairo, Egypt. Olive oil cake was kindly donated from Borg Al Arab for Industry, Alexandria, Egypt. All the substrates were thoroughly washed with tap water, dried at $80{ }^{\circ} \mathrm{C}$ in an air-circulation oven to reduce their moisture content (up to $5 \%$ ), then ground in an electric mill (model 4630, 25000 rpm; Vigor Industrial Co., Ltd, Hong Kong, PR China) to uniform size (no. 6 mesh) and finally stored in plastic bags at room temperature (25 ${ }^{\circ} \mathrm{C}$ ) for later use. Different types of oil (sunflower, mustard, olive, coconut, sesame, castor, corn, black seed, almond and flaxseed) were obtained from a local hypermarket, Cairo, Egypt. Buffers used in the present research ( $\mathrm{KCl}-\mathrm{HCl}, \mathrm{pH}=2-3$, citrate-phosphate, $\mathrm{pH}=3-6$, phosphate, $\mathrm{pH}=6-8$, Tris- $\mathrm{HCl}, \mathrm{pH}=7-9$, and carbonate-bicarbonate, $\mathrm{pH}=9-11$ ) were prepared as described by Gomori (11).

\section{Microorganism isolation, morphological characterisation and inoculum preparation}

In the current work, thirty fungal strains were isolated locally from different soil samples from Mit Ghamr, El Dakahleya, Egypt, using serial dilution plate technique (12). The soil sample suspensions were inoculated on potato dextrose agar (PDA) medium containing $5 \mathrm{mg} / \mathrm{L}$ of streptomycin at $\mathrm{pH}=5.0$ and incubated at $30{ }^{\circ} \mathrm{C}$ for $72 \mathrm{~h}$. Subsequently, the separate and distinct colonies were picked and subcultured onto PDA slants, incubated at 30 ${ }^{\circ} \mathrm{C}$ for 7 days and maintained at $4{ }^{\circ} \mathrm{C}$.
The morphological and cultural characterisation of the highest lipase-producing fungal isolate including shape, size and colony characteristics (colour, shape, surface, elevation and edge) were investigated for identification purpose (13). The inoculum was prepared from one-week-old PDA slant. Conidia were scraped and $5.0 \mathrm{~mL}$ of sterile saline water containing $0.1 \%$ Tween 80 (by volume) was added to each slant.

\section{S rRNA gene sequencing and phylogenetic tree}

The fungal strain was cultivated in PDA medium at $30{ }^{\circ} \mathrm{C}$ for seven days and directly used for the amplification of fungal $18 \mathrm{~S}$ rRNA gene by polymerase chain reaction (PCR). Two universal 18S rRNA gene primers ITS1 5'-TCCGTAGGTGAACCTGCGG-3' and ITS4 5'-TCCTCCGCTTATTGATATGC-3' were used. PCR was performed in a final volume of $25 \mu \mathrm{L}$ composed of $1 \mu \mathrm{L}$ of fungal culture as template DNA, $12.5 \mu \mathrm{L}$ of Taq PCR Master Mix (Promega, Mannheim, Germany), containing Taq DNA polymerase $0.5 \mathrm{U} / \mu \mathrm{L}, 500 \mu \mathrm{M}$ of each $\mathrm{dNTP}, 20 \mathrm{mM}$ of Tris- $\mathrm{HCl}(\mathrm{pH}=8.3), 100 \mathrm{mM}$ of $\mathrm{KCl}, 3 \mathrm{mM}$ of each $\mathrm{MgCl}_{2}$ and Bromophenol Blue, $1 \mu \mathrm{L}$ of each primer $(10 \mu \mathrm{M})$, and $9.5 \mu \mathrm{L}$ of double distilled $\mathrm{H}_{2} \mathrm{O}$. PCR procedure was as follows: 35 cycles of denaturation at $95^{\circ} \mathrm{C}$ for $1 \mathrm{~min}$, annealing at $55^{\circ} \mathrm{C}$ for $30 \mathrm{~s}$ and extension at $72{ }^{\circ} \mathrm{C}$ for $2 \mathrm{~min}$, and final extension at $72{ }^{\circ} \mathrm{C}$ for $10 \mathrm{~min}$.

PCR products were separated by electrophoresis (MSMINIDUO MultiSUB Mini, Cleaver Scientific Ltd., Rugby, Warwickshire, UK) in agarose gel stained with ethidium bromide and visualised under UV light to confirm its purity, quantity and size, using Tris/borate/EDTA (TBE) buffer containing $1 \mu \mathrm{g} / \mathrm{mL}$ of ethidium bromide. DNA fragments were extracted from the gel using Core Bio Gel Extraction Kit (RKT13; Chromous Biotech, Karnataka, India) and finally sequenced. The retrieved gene sequences were aligned and compared to the nucleotide sequences of some fungal strains in GenBank database of the National Centre for Biotechnology Information (NCBI) by using Basic Local Alignment Search Tool (BLAST) $(14,15)$. Phylogenetic tree was constructed by utilising MEGA v. 4.0 software (16).

\section{Determination of aflatoxins}

Detection of aflatoxins of lipase-producing fungal strain was performed using high-performance liquid chromatography (1100 HPLC; Agilent Technology, Santa Clara, CA, USA) technique according to AOAC method 971.24 (17). A mobile phase including water/acetonitrile/mehanol in ratio 240:120:40 was used (18). Data observed were recorded with Millennium Chromatography Manager software (19).

\section{Qualitative and quantitative screening}

The isolated fungal strains were screened for lipase production using rapid qualitative tributyrin Phenol Red agar plate (TPRA) method (20). Chromogenic substrate plates were prepared by using Phenol Red (0.01\%) along with $1 \%$ tributyrin, $0.1 \% \mathrm{CaCl}_{2}$ and $2 \%$ agar adjusted to $\mathrm{pH}=7.3$. Agar wells of $8 \mathrm{~mm}$ in diameter were made with the help of sterilised cork borer and loaded with $100 \mu \mathrm{L}$ of spore suspension $\left(1.5 \cdot 10^{7}\right.$ spore/mL) of each fungal strain 
under aseptic conditions. The inoculated plates were incubated at $28^{\circ} \mathrm{C}$ for $48 \mathrm{~h}$ and diameters of the developed yellow zones were measured in $\mathrm{mm}$. The change in colour of phenol from red to bright yellow was used as an indicator of lipolytic activity. The fungal strains that exhibited the highest yellow zones around the colonies indicating lipase production were selected for further studies.

Based on the qualitative analysis test, the fungal strains that exhibited the highest yellow zones were further screened using SSF for quantitative enzyme assay. A mass of $5 \mathrm{~g}$ of wheat bran was added into 250-mL Erlenmeyer flasks, containing synthetic oil-based (SOB) medium (up to $70 \%$ moisture) composed of (in g/L): $\mathrm{NaNO}_{3}$ $0.5, \mathrm{MgSO}_{4} \cdot 7 \mathrm{H}_{2} \mathrm{O} 0.5, \mathrm{KCl} 0.5, \mathrm{KH}_{2} \mathrm{PO}_{4} 2.0$, yeast extract 1.0 , Bacto $^{\mathrm{TM}}$ peptone 5.0 adjusted to $\mathrm{pH}=6.0$ and supplemented with essential olive oil ( $1 \%$ by volume). After sterilisation (LAC-J0805 autoclave; Daihan Labtech Co., Ltd., Namyangju-city, Kyonggi-do, Korea) at $121^{\circ} \mathrm{C}$ for 20 $\mathrm{min}$, the flasks were cooled, inoculated with $1.0 \mathrm{~mL}$ of spore inoculum $\left(1.27 \cdot 10^{7}\right.$ spore/mL) and incubated (FOC225E incubator; Velp Scientifica Srl, Milan, Italy) at $30{ }^{\circ} \mathrm{C}$ for 7 days. After incubation period, $100 \mathrm{~mL}$ of sterilised distilled water were transferred to each flask and the mixture was shaken in refrigerated incubator shaker (Innova ${ }^{\circledR}$ 4230; New Brunswick ${ }^{\mathrm{TM}}$ Scientific, Scituate, MA, USA) for $1 \mathrm{~h}$ at $180 \mathrm{rpm}$ at room temperature. The developed suspension was squeezed through muslin cloth and centrifuged (refrigerated Sigma 3-18KS centrifuge, Sigma Laborzentrifugen $\mathrm{GmbH}$, Osterode am Harz, Germany) at $5000 \times g$ and $4{ }^{\circ} \mathrm{C}$ for $15 \mathrm{~min}$. The obtained supernatant was used for lipase assay.

\section{Lipase production in $S m F$}

One-mL aliquots of spore suspension $\left(1.27 \cdot 10^{7}\right.$ spore/ $\mathrm{mL}$ ) were used to inoculate $250-\mathrm{mL}$ Erlenmeyer flasks containing $50 \mathrm{~mL}$ of SOB medium. The flasks were incubated at $30{ }^{\circ} \mathrm{C}$ on a rotary shaker (Innova ${ }^{\circledR} 4230$ shaker incubator; New Brunswick Scientific) at 150 rpm for a week. After incubation, the mycelia were harvested by filtration and the culture filtrates were centrifuged (refrigerated Sigma $3-18 \mathrm{KS}$ centrifuge) at $5000 \times g$ and $4{ }^{\circ} \mathrm{C}$ for $15 \mathrm{~min}$. The obtained clear supernatant was used for enzyme assay.

\section{Enzyme assay using $p N P P$ substrate}

$p$-Nitrophenyl palmitate ( $p$ NPP) was used as a substrate for rapid measurement of lipase activity as described by Pera et al. (21) but with slight modifications. Substrate solution was prepared as follows: $1.0 \mathrm{~mL}$ of solution A (40 mg of $p$ NPP in $12 \mathrm{~mL}$ of isopropanol) was added dropwise with stirring to $19 \mathrm{~mL}$ of solution $\mathrm{B}(0.1 \mathrm{~g}$ of gum arabic and $0.4 \mathrm{~mL}$ of Triton X-100 in $90 \mathrm{~mL}$ of distilled water) and the obtained emulsion remained stable up to $2 \mathrm{~h}$. The enzyme assay mixture, composed of $0.5 \mathrm{~mL}$ of Tris- $\mathrm{HCl}$ buffer $(\mathrm{pH}=8.0,0.1 \mathrm{M}), 1.0 \mathrm{~mL}$ of the substrate solution, $0.1 \mathrm{~mL}$ of suitably diluted enzyme and $1.4 \mathrm{~mL}$ of distilled water, was incubated at $40^{\circ} \mathrm{C}$ for $15 \mathrm{~min}$. The reaction was terminated by the addition of isopropanol $(0.2$ $\mathrm{mL})$ and the released $p$-nitrophenol was measured at 410 $\mathrm{nm}$ in Cary-100 UV-Vis spectrophotometer (Agilent Technologies, Frankfurt, Germany). One unit of enzyme activ- ity is defined as the amount of lipase that releases one $\mu \mathrm{mol}$ of $p$-nitrophenol per min under the standard conditions. Enzyme activity was expressed in U/g on dry mass basis.

\section{Optimisation of various physicochemical parameters}

Four different media were used in the present study, each containing $5 \mathrm{~g}$ of wheat bran supplemented with olive oil $(1 \%)$ at moisture content of $70 \%$ and adjusted to $\mathrm{pH}=6.0$. Different production media were designed as follows (in g/L): medium I: $\mathrm{KNO}_{3} 2.5, \mathrm{KH}_{2} \mathrm{PO}_{4} 1.0, \mathrm{MgSO}_{4}$. $7 \mathrm{H}_{2} \mathrm{O} 1.0$ and casein hydrolysate 20; medium II: Tween 80 5.0 and $\left(\mathrm{NH}_{4}\right)_{2} \mathrm{SO}_{4}$ 4.0; medium III: $\mathrm{NaNO}_{3} 0.5, \mathrm{KCl} 0.5$, $\mathrm{MgSO}_{4} \cdot 7 \mathrm{H}_{2} \mathrm{O} 0.5, \mathrm{KH}_{2} \mathrm{PO}_{4} 2.0$, yeast extract 1.0 , Bacto ${ }^{\mathrm{TM}}$ peptone 5.0, and medium IV: maltose 50 and Bacto ${ }^{\mathrm{TM}}$ peptone 30.

Various agro-industrial substrates (wheat bran, wheat germ, sunflower oil cake, safflower oil cake, cotton seed waste, jojoba oil cake, rice straw, rice husk, rice bran and olive oil cake) were screened for optimal enzyme production in SSF by the highest lipase-producing fungal strain. The chosen substrate was further used in the subsequent studies. Optimum temperature for lipase production was studied by varying the incubation temperatures from 25 to $45^{\circ} \mathrm{C}$.

The influence of initial $\mathrm{pH}$ of the production medium on enzyme formation was examined by changing the $\mathrm{pH}$ of the medium from 3.0 to 8.0 (using $1 \mathrm{M} \mathrm{HCl}$ or $1 \mathrm{M}$ $\mathrm{NaOH}$ ). The optimal incubation period of enzyme production was investigated by incubating the inoculated media up to 12 days and the lipase activity in the samples was analysed every $24 \mathrm{~h}$ as described above. To study the impact of moisture content on enzyme production, the selected substrate was moistened within the range of 33-90 $\%$ (by volume per mass). Optimum inoculum volume per mass ratio for enzyme production was evaluated by using 5-60 \% of inoculum prepared as mentioned before. A volume of $1 \mathrm{~mL}$ of spore inoculum contained $1.27 \cdot 10^{7}$ spore/ $\mathrm{mL}$.

An experiment was designed to test the effect of various types of oil (sunflower, mustard, olive, coconut, sesame, castor, corn, black seed, almond and flaxseed at $1 \%$ ) on enzyme production during SSF. The effect of metal ions on enzyme production was tested by adding individually $\mathrm{K}^{+}, \mathrm{Na}^{+}, \mathrm{Mg}^{2+}, \mathrm{Ba}^{2+}, \mathrm{Ca}^{2+}$ and $\mathrm{Co}^{2+}$ in the chloride form at $0.05 \%$ (by mass).

\section{Partial enzyme purification}

At the end of incubation period, the crude enzyme was extracted as described previously and precipitated by adding various mass fractions of ammonium sulfate solutions (from 20 up to $100 \%$ saturation level) with constant stirring at $4{ }^{\circ} \mathrm{C}$ for $24 \mathrm{~h}$. The precipitated proteins were separated by centrifugation at $10000 \times g$ and $4{ }^{\circ} \mathrm{C}$ for $15 \mathrm{~min}$, suspended in a minimal volume $(5 \mathrm{~mL})$ of $0.1 \mathrm{M}$ Tris- $\mathrm{HCl}$ buffer $(\mathrm{pH}=8.0)$, dialysed against the same buffer $(0.05 \mathrm{M})$ overnight at $4{ }^{\circ} \mathrm{C}$ using a dialysis membrane (Visking size 3-20/32, diameter of $15.9 \mathrm{~mm}$ and capacity of $1 \mathrm{~mL} / \mathrm{cm}$; Medicell Membranes Ltd, London, UK) and examined for lipase activity (fraction with the highest enzyme activity was selected for further studies). 


\section{Enzyme characterisation}

The effect of $\mathrm{pH}$ on the partially purified enzyme was evaluated by monitoring enzyme activity in the $\mathrm{pH}$ range of 3-10 (using $0.1 \mathrm{M}$ sodium acetate buffer, $\mathrm{pH}=3-5$, phosphate buffer, $\mathrm{pH}=6-7$, Tris- $\mathrm{HCl}$ buffer, $\mathrm{pH}=7-9$ and carbonate-bicarbonate buffer, $\mathrm{pH}=9-10$ ). The enzyme stability at various $\mathrm{pH}$ values was determined by incubating the enzyme (in the absence of substrate) at desired $\mathrm{pH}$ for $2 \mathrm{~h}$ and assaying the residual enzyme activity as described previously. The activity of non-incubated enzyme was regarded as the control (100\%).

The optimal temperature for lipase activity was measured by conducting the enzyme-substrate reaction at various temperatures $\left(30-90{ }^{\circ} \mathrm{C}\right.$ at $5{ }^{\circ} \mathrm{C}$ intervals) at $\mathrm{pH}=8.0$ and the concentration of liberated $p$-nitrophenol was measured. Thermal stability behaviour of the partially purified lipase was determined in terms of residual activity after incubation of enzyme at desired temperature (50, 55, 60 and $70^{\circ} \mathrm{C}$ ) up to $1 \mathrm{~h}$. The activity of the thermally non-treated enzyme was used as control $(100 \%)$.

\section{Protein determination}

The concentration of protein was determined as described by Bradford (22) and bovine serum albumin (BSA) was used as a standard. Bradford reagent was prepared by dissolving $100 \mathrm{mg}$ of Coomassie Brilliant Blue G-250 (Sigma-Aldrich) in $50 \mathrm{~mL}$ of $95 \%$ ethanol, then $100 \mathrm{~mL}$ of $85 \%$ phosphoric acid were added to the mixture and the resulting reagent was filled to $1 \mathrm{~L}$ with distilled water and stored in dark until use. For protein quantification, $0.1 \mathrm{~mL}$ of diluted enzyme solution was transferred into a clean test tube, $5 \mathrm{~mL}$ of dye reagent were added and the sample was allowed to stand for 5-10 $\mathrm{min}$ at room temperature, then measured at $\lambda=595 \mathrm{~nm}$ (Cary-100 UV-Vis spectrophotometer; Agilent Technologies, Göttingen, Germany).

\section{Statistical analysis}

Data reported represent the mean value of triplicate trials with standard deviation (S.D.). The software used to calculate the data was Excel 2010 (Microsoft Corp., Redmond, WA, USA).

\section{Results and Discussion}

\section{Qualitative analysis of lipase production by isolated fungal strains}

In the rapid qualitative tributyrin Phenol Red agar plate (TPRA) method, out of thirty fungal strains screened for extracellular lipase activity, seventeen gave positive test result with various degrees depending on the intensity of the produced yellow colour. However, fungus 25A exhibited the largest yellow zone (Fig. 1a; for colour version see www.ftb.com.hr) followed by fungus 27A. Yellow colour can be interpreted as the consequence of $\mathrm{pH}$ changes in the media caused by increased level of fatty acids due to their release from triglycerides by the action of lipase. Many investigators reported the validity of the previously mentioned method for the primary screening of lipase from different filamentous fungal strains (23-25). However, for further confirmation spectrophotometric quantitative method was performed.
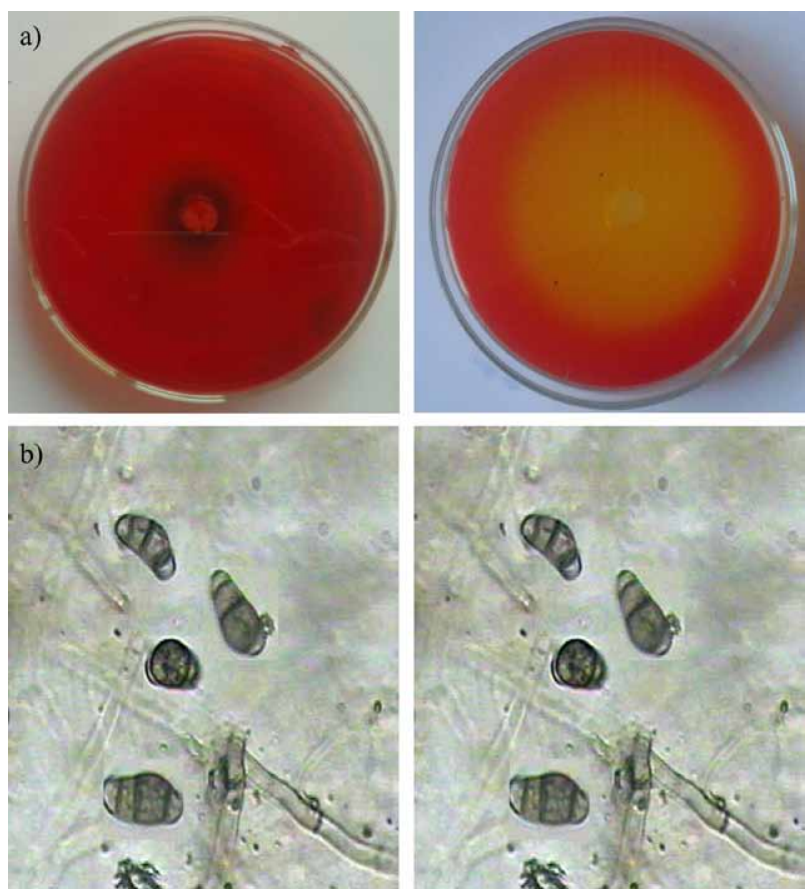

Fig. 1. A novel fungus Curvularia sp. DHE 5 (GenBank accession no. KT354967): a) qualitative analysis of lipase production using tributyrin Phenol Red agar plate (TPRA) method; left side $=$ control, right side $=$ agar plate containing tributyrin as substrate with Phenol Red as $\mathrm{pH}$ indicator, and b) microscopic examination of Curvularia sp. DHE 5; conidiophores were $5 \mu \mathrm{m}$ in diameter and the conidia were golden brown, or dark reddish brown, broadly ellipsoidal and unilaterally flattened to distinctly geniculate with 4 septa

\section{Quantitative analysis of lipase production by isolated fungal strains}

Based on the qualitative screening results, the fungal strains that exhibited the highest yellow zones were further chosen for quantitative analysis using $p \mathrm{NPP}$ as a substrate. The reported results (Table 1) indicated that almost all selected fungi from the tested set produced extracellular alkaline lipase with different proportions. However, the most potent lipase producer was found to be fungus 25A $((55.9 \pm 2.5) \mathrm{U} / \mathrm{g})$, followed by fungus $28 \mathrm{~A}((44.4 \pm 1.9) \mathrm{U} / \mathrm{g})$ and fungus $27 \mathrm{~A}((39.4 \pm 1.2) \mathrm{U} / \mathrm{g})$. The lowest enzyme production was obtained with fungal strains $12 \mathrm{~A}, 2 \mathrm{~A}$ and $29 \mathrm{~A}$, respectively. These results were higher than those reported by Cihangir and Sarikaya (26) for extracellular lipase production from Aspergillus sp. (17 U/mL) isolated from a soil sample in Turkey. In another study, Kaushik et al. (27) reported the production of an extracellular lipase from Aspergillus carneus with a maximum activity of $13 \mathrm{U} /$ mL. In SSF, Kempka et al. (28) and Vargas et al. (29) reported optimum lipase production of 40 and $30 \mathrm{U} / \mathrm{g}$ in Penicillium verrucosum and $P$. simplicissimum, respectively. It is worth mentioning that fungal strains $5 \mathrm{~A}, 22 \mathrm{~A}$ and $23 \mathrm{~A}$ did not show any lipase activity when grown in solid-state fermentation.

\section{Evaluation of aflatoxins and identification of the selected fungal strain}

In the present study, toxicity test was performed to confirm the selection of the highest lipase-producing fun- 
Table 1. The results of qualitative and quantitative analyses of extracellular alkaline lipase production (on dry mass basis) by locally isolated filamentous fungi

\begin{tabular}{|c|c|c|}
\hline Microorganism & $d / \mathrm{mm}$ & Lipase activity/(U/g) \\
\hline Isolate $1 \mathrm{~A}$ & 43 & $15.9 \pm 1.3$ \\
\hline Isolate $2 \mathrm{~A}$ & 26 & $6.7 \pm 0.3$ \\
\hline Isolate $3 \mathrm{~A}$ & - & N.D. \\
\hline Isolate $4 \mathrm{~A}$ & - & N.D. \\
\hline Isolate $5 \mathrm{~A}$ & 9.0 & 0.00 \\
\hline Isolate $6 \mathrm{~A}$ & - & N.D. \\
\hline Isolate 7A & - & N.D. \\
\hline Isolate $8 \mathrm{~A}$ & 16 & $18.5 \pm 1.5$ \\
\hline Isolate 9A & - & N.D. \\
\hline Isolate $10 \mathrm{~A}$ & - & N.D. \\
\hline Isolate $11 \mathrm{~A}$ & - & N.D. \\
\hline Isolate 12A & 18 & $0.7 \pm 0.2$ \\
\hline Isolate $13 \mathrm{~A}$ & 30 & $23.2 \pm 1.0$ \\
\hline Isolate $14 \mathrm{~A}$ & - & N.D. \\
\hline Isolate $15 \mathrm{~A}$ & - & N.D. \\
\hline Isolate $16 \mathrm{~A}$ & - & N.D. \\
\hline Isolate 17A & - & N.D. \\
\hline Isolate $18 \mathrm{~A}$ & - & N.D. \\
\hline Isolate 19A & 29 & $25.4 \pm 1.1$ \\
\hline Isolate $20 \mathrm{~A}$ & 16 & $18.0 \pm 1.0$ \\
\hline Isolate $21 \mathrm{~A}$ & 11 & $10.3 \pm 0.8$ \\
\hline Isolate 22A & 10 & 0.00 \\
\hline Isolate 23A & 11 & 0.00 \\
\hline Isolate $24 \mathrm{~A}$ & - & N.D. \\
\hline Isolate $25 \mathrm{~A}$ & 80 & $55.9 \pm 2.5$ \\
\hline Isolate $26 \mathrm{~A}$ & 43 & $18.6 \pm 1.1$ \\
\hline Isolate 27A & 55 & $39.4 \pm 1.2$ \\
\hline Isolate $28 \mathrm{~A}$ & 37 & $44.4 \pm 1.9$ \\
\hline Isolate 29A & 32 & $7.3 \pm 0.7$ \\
\hline Isolate $30 \mathrm{~A}$ & 28 & $8.3 \pm 0.7$ \\
\hline
\end{tabular}

Data are expressed as mean value \pm S.D. of triplicate measurements. $-=$ no formation of yellow colour, $d=$ diameter of the yellow zone in $\mathrm{mm}$.

N.D. $=$ not detected

gal strain according to AOAC method 971.24 (17). The reported results clearly indicated that fungus $25 \mathrm{~A}$ was a non-mycotoxin-producing fungal strain. Isolate $25 \mathrm{~A}$ was identified through morphological and culture characteristics as Curvularia lunata (Fig. 1b). PCR amplification of 185 rRNA gene, using the primers ITS1 and ITS4, revealed efficient amplification: a single band of $550 \mathrm{bp}$. According to $18 \mathrm{~S}$ rRNA gene sequence similarities, the close relatives were Curvularia lunata QH-CL1 (99\%), Curvularia lunata 3K0205 (98 \%) and Curvularia lunata GZJZ201302 (97\%). Therefore, the phylogenetic analysis suggests that strain DHE 5 is a new Curvularia species and the nucleotide sequences of $18 \mathrm{~S}$ rRNA genes were deposited to GenBank under the accession number KT354967 (Fig. 2). To the best of our knowledge, no lipases produced by Curvularia sp. have been described; therefore, this finding justified the selection of this fungal strain for further studies.

\section{Comparative evaluation of SmF and SSF systems}

Extracellular lipase production by Curvularia sp. in SSF of $(56.2 \pm 0.4) \mathrm{U} / \mathrm{g}$ on dry mass basis was found to be 7 -fold higher than that in SmF using SOB medium $((7.8 \pm 0.1) \mathrm{U} / \mathrm{mL})$ (data not shown). The lower enzyme yield when using SOB medium is thought to result from the complexity of the medium components and increased accumulation of intermediate metabolites. Therefore, this study indicates that SSF is more suitable for enzyme production than SmF due to its superior productivity, reduced energy requirements and low wastewater output. Besides, the substrates utilised by microorganisms for enzyme production in SSF are much cheaper than the SmF substrates. Mateos-Díaz et al. (30) reported extracellular lipase activities of $1500 \mathrm{U} / \mathrm{g}$ and $50 \mathrm{U} / \mathrm{mL}$ in Rhizopus homothallicus cultivated by SSF and SmF, respectively. Furthermore, de Azeredo et al. (31) obtained lipase activities of $17 \mathrm{U} / \mathrm{g}$ and $12 \mathrm{U} / \mathrm{mL}$ when Penicillium restrictum was cultivated under SSF and SmF conditions, respectively.

\section{Optimisation of different physicochemical parameters for lipase production}

Effect of medium composition on lipase production

The physiological studies were started by studying the effect of medium type on extracellular lipase production by Curvularia sp. DHE 5. The reported results indicated that medium IV was the best medium for lipase production $((62.2 \pm 0.7) \mathrm{U} / \mathrm{g})$, while medium I ((57.1 \pm 0.6$)$ $\mathrm{U} / \mathrm{g})$ and medium III $((52.3 \pm 0.5) \mathrm{U} / \mathrm{g})$ gave moderate lipase yield (data not shown). The lowest enzyme yield $((44.5 \pm 0.3) \mathrm{U} / \mathrm{g})$ was observed with medium II, which is in agreement with the observations of Lin et al. (23). Sarkar et al. (24) stated that the production of lipase is improved when using complex medium instead of the simple one, while Rodriguez et al. (25) reported that lipase formation by Rhizopus hornothallicus was highly affected by medium constituents besides $\mathrm{pH}$, temperature and inoculum size.

\section{Substrate screening}

In the present study, the highest enzyme production (in U/g on dry mass basis) by Curvularia sp. was reported when using wheat bran as a medium $(62.9 \pm 1.3)$, followed by sunflower oil cake $(57.3 \pm 0.9)$, cotton seed waste $(56.8 \pm 1.1)$ and jojoba oil cake $(54.3 \pm 0.7)$ (Fig. 3). These results are congruent with those observed during enzyme production by Aspergillus sp. (32) and Aspergillus niger (33). Among different agro-industrial residues, wheat bran is considered as the universal substrate due to its high nutritional value and low lignin content, which is very helpful for growth initiation and replication of microorganisms. Besides that, wheat bran provides a large surface area because it remains loose even under increased moisture compared to other substrates (34).

\section{Incubation period}

The impact of time course on lipase production by Curvularia sp. DHE 5 grown under SSF using wheat bran 


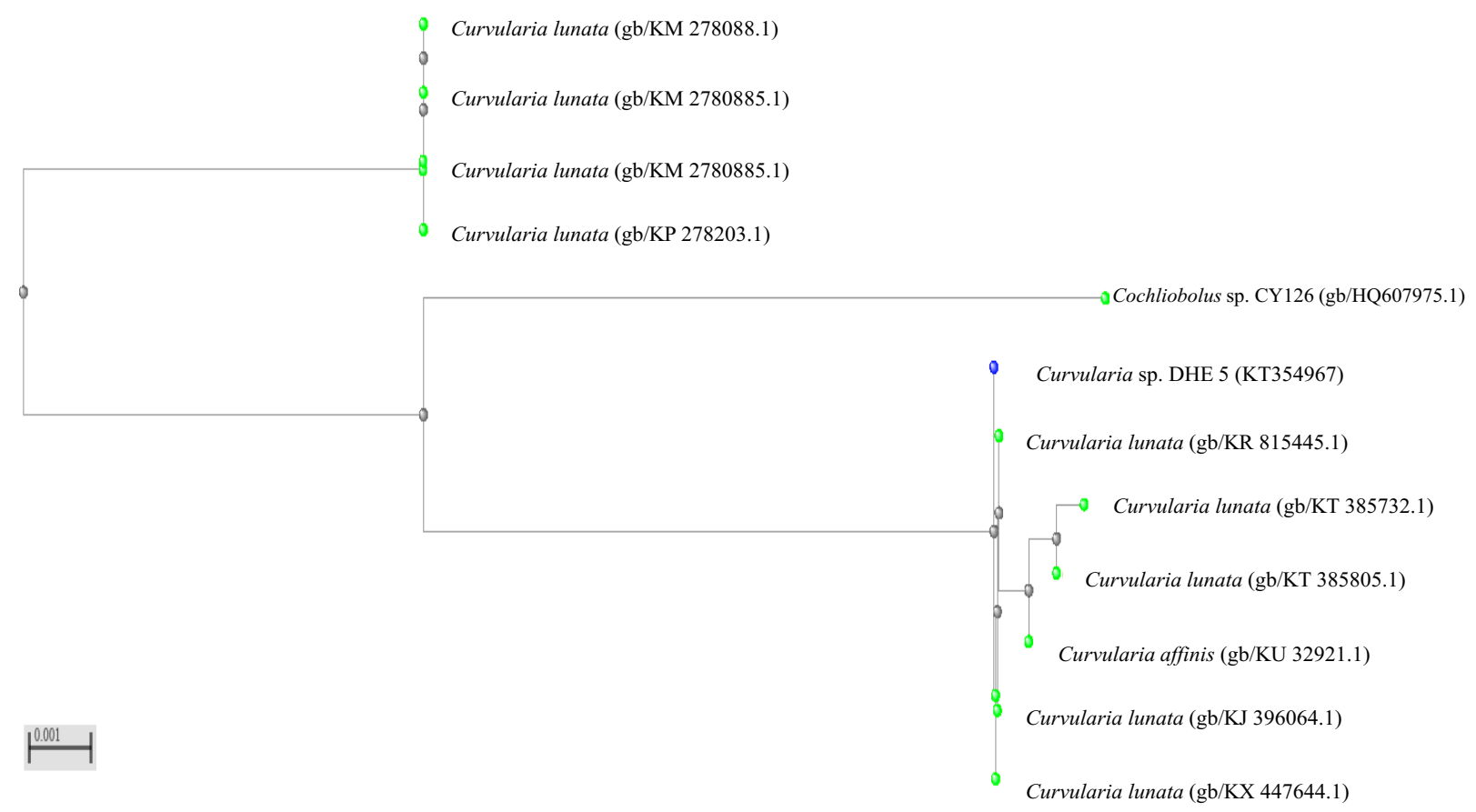

Fig. 2. Phylogenetic analysis of Curvularia sp. DHE 5 based on the results of polymerase chain reaction (PCR) amplification of the $18 \mathrm{~S}$ rRNA gene

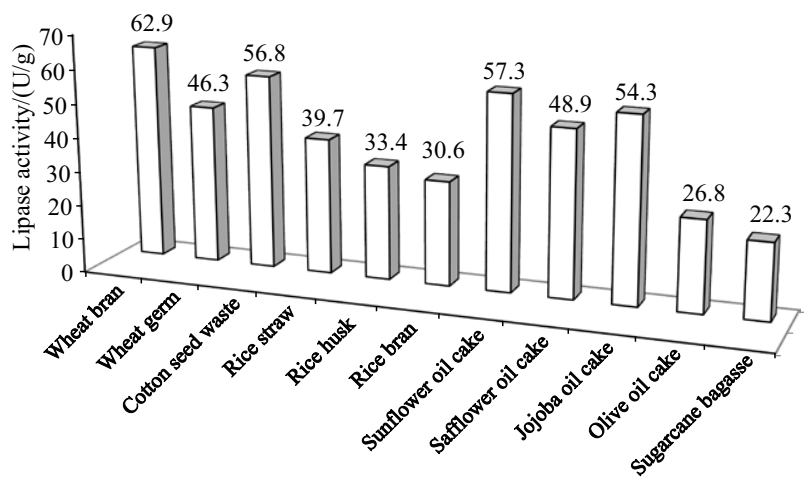

Fig. 3. Influence of various agro-industrial residues on lipase production (on dry mass basis) by Curvularia sp. DHE 5

as substrate was evaluated. Results presented in Table 2 show that optimal enzyme production of $(63.4 \pm 1.0) \mathrm{U} / \mathrm{g}$ on dry mass basis was achieved on the seventh day; however, a reduction in enzyme yield was detected with a prolonged incubation period, which might result from the reduction of nutrients or change in $\mathrm{pH}$ of the medium or denaturation of the enzyme (35). These results are consistent with Rajan and Nair (36) who reported that maximum enzyme yield from Aspergillus fumigatus was found after seven days of fermentation. Mahadik et al. (33) observed optimal lipolytic activity of $A$. niger lipase on the fifth day of incubation, while Kamini et al. (37) and Gutarra et al. (38) reported that the highest yield of lipase using $A$. niger and $P$. simplicissimum, respectively, was achieved after $72 \mathrm{~h}$ of fermentation.

\section{Effect of temperature}

Incubation temperature strongly affects the biochemical activities of different microorganisms (39). Results shown in Table 2 clearly indicated that the maximal lipase production of $(62.4 \pm 1.1) \mathrm{U} / \mathrm{g}$ by Curvularia sp. DHE 5 was observed at incubation temperature of $30{ }^{\circ} \mathrm{C}$ after seven days, while a slight decrease in enzyme production was reported at temperatures below optimum. Furthermore, a drastic drop in enzyme yield was noticed at the temperatures above the optimum with least activity detected above $40{ }^{\circ} \mathrm{C}$. These negative impacts might result from the production of proteases at elevated temperatures. Similar results were reported by Rehman et al. (40) and Zhang and Zeng (41) for lipase production by Penicillium notatum and Pseudomonas sp. 7323, respectively, while the optimal temperatures for lipase formation by Ganoderma lucidum (42) and Colletotrichum gloeosporioides (43) were observed at 26.5 and $25^{\circ} \mathrm{C}$, respectively.

Influence of initial medium $\mathrm{pH}$

The initial $\mathrm{pH}$ of the growth medium is considered as an imperative parameter and greatly affects the growth and enzyme production by various microorganisms in SSF. However, filamentous fungi are capable of growing in a wide $\mathrm{pH}$ range in SSF, because solid substrates have a better buffering capacity (44). In this study, maximum lipase production of $(71.2 \pm 1.1) \mathrm{U} / \mathrm{g}$ on dry mass basis by Curvularia sp. DHE 5 was reported at initial $\mathrm{pH}=7$ on the seventh day of incubation at $30{ }^{\circ} \mathrm{C}$, while a reduction in lipase yield to $(53.4 \pm 1.8) \mathrm{U} / \mathrm{g}$ (Table 2) was detected when the $\mathrm{pH}$ value increased from 7 to 8 . Likewise, optimum $\mathrm{pH}$ for lipase production by Penicillium chrysogenum was observed near neutral value (45). Rehman et al. (40) and Lin et al. (23) reported that $\mathrm{pH}=5.5$ was the optimal for lipase production in P. notatum and Antrodia cinnamomea, respectively. On the other hand, our result is lower than that reported for lipase production by Fusarium solani, which was $\mathrm{pH}=8.6$ (46). 
Table 2. Effect of different physical parameters on extracellular alkaline lipase production (on dry mass basis) by Curvularia sp. DHE 5 in solid-state fermentation (SSF)

\begin{tabular}{|c|c|}
\hline$t$ (incubation)/day & Alkaline lipase activity/(U/g) \\
\hline 3 & $23.7 \pm 0.2$ \\
\hline 4 & $40.2 \pm 0.5$ \\
\hline 5 & $47.6 \pm 0.6$ \\
\hline 6 & $58.2 \pm 0.8$ \\
\hline 7 & $63.4 \pm 1.0$ \\
\hline 8 & $54.3 \pm 0.8$ \\
\hline 9 & $49.6 \pm 0.5$ \\
\hline 10 & $41.7 \pm 0.4$ \\
\hline \multicolumn{2}{|l|}{ Temperature $/{ }^{\circ} \mathrm{C}$} \\
\hline 25 & $48.9 \pm 0.5$ \\
\hline 30 & $62.4 \pm 1.1$ \\
\hline 35 & $24.5 \pm 0.3$ \\
\hline 40 & $5.8 \pm 0.2$ \\
\hline 45 & $1.4 \pm 0.2$ \\
\hline \multicolumn{2}{|l|}{$\mathrm{pH}$} \\
\hline 3.0 & $16.6 \pm 0.1$ \\
\hline 4.0 & $22.5 \pm 0.3$ \\
\hline 5.0 & $44.2 \pm 0.7$ \\
\hline 6.0 & $57.4 \pm 0.8$ \\
\hline 7.0 & $71.2 \pm 1.1$ \\
\hline 7.5 & $67.8 \pm 1.1$ \\
\hline 8.0 & $53.4 \pm 1.8$ \\
\hline \multicolumn{2}{|l|}{$w($ moisture $) / \%$} \\
\hline 33 & $46.3 \pm 0.5$ \\
\hline 50 & $54.2 \pm 0.6$ \\
\hline 66 & $63.4 \pm 0.8$ \\
\hline 70 & $72.8 \pm 1.0$ \\
\hline 75 & $70.9 \pm 1.2$ \\
\hline 80 & $59.3 \pm 0.8$ \\
\hline 85 & $52.5 \pm 1.0$ \\
\hline \multicolumn{2}{|c|}{ Inoculum size/(spore/mL) } \\
\hline $0.64 \cdot 10^{7}$ & $75.6 \pm 1.2$ \\
\hline $1.27 \cdot 10^{7}$ & $80.8 \pm 2.1$ \\
\hline $2.54 \cdot 10^{7}$ & $67.4 \pm 2.2$ \\
\hline $3.81 \cdot 10^{7}$ & $55.1 \pm 1.0$ \\
\hline $5.08 \cdot 10^{7}$ & $48.8+0.9$ \\
\hline $6.35 \cdot 10^{7}$ & $33.4 \pm 0.3$ \\
\hline
\end{tabular}

Data are expressed as mean value $\pm S$.D. of triplicate measurements

\section{Effect of moisture level}

In the present investigation, maximum lipase yield of $(72.8 \pm 1.0) \mathrm{U} / \mathrm{g}$ on dry mass basis was reported at $70 \%$ (by volume per mass) moisture content on the seventh day of incubation at $30^{\circ} \mathrm{C}$ and initial $\mathrm{pH}=7.0$ (Table 2). However, at higher or lower moisture content, a lower enzyme yield was achieved. At higher moisture content, the lower enzyme yield might result from the decrease of substrate porosity, alternation of substrate particle structure and development of stickiness, which leads to low oxygen transfer and diffusion, while at lower moisture levels the reduction of nutrient solubility results in an improper swelling with a higher water tension that decreased the enzyme yield $(35,44)$. Sun and $\mathrm{Xu}(44)$ and Imandi et al. (47) reported the same results for lipases produced by $Y$. lipolytica and Rhizopus chinensis, respectively. Rehman et al. (40) investigated optimum lipase production of 3426 U/g by Penicillium notatum at $60 \%$ moisture level.

\section{Inoculum concentration}

Results shown in Table 2 clearly revealed that maximum lipase production of $(80.8 \pm 2.2) \mathrm{U} / \mathrm{g}$ was obtained with $1.0 \mathrm{~mL}\left(1.27 \cdot 10^{7} \mathrm{spore} / \mathrm{mL}\right)$ of inoculum after seven days of fermentation at $30^{\circ} \mathrm{C}$ and $\mathrm{pH}=7.0$. In addition, at higher or lower inoculum size, a negative effect on lipase production was detected. At lower inoculum level, the microbial biomass cannot proliferate quickly; hence, substrate degradation is slow, which subsequently affects the production of metabolites. The inhibitory effect on enzyme production at higher inoculum size might result from the depletion of the nutrients and oxygen available in the growth medium (48-51).

Supplementation of wheat bran with various types of oil

Data shown in Fig. 4 clearly indicated that all the tested oil types were suitable for enzyme production but at various extents; however, olive oil was shown to be the best inducer for the production of lipase $((83.1 \pm 2.2) \mathrm{U} / \mathrm{g})$ by Curvularia sp. DHE 5 using wheat bran as substrate in SSF after seven days of growth at incubation temperature of $30^{\circ} \mathrm{C}$ and initial $\mathrm{pH}=7.0$. These results might be correlated with the presence of high percentage of oleic acid $(28 \%)$ in olive oil, while the other oils contain higher levels of linoleic acid (30-50 \%) (52). Iwai and Tsujisaka (53) reported that the optimum lipase production was found to be correlated with the higher content of oleic acid in the oil. Similar results were reported for maximum lipase production from Aspergillus oryzae (54) and Penicillium wortmanii (55). Adinarayana et al. (56) observed the optimal production of lipase in Aspergillus sp. of $1664 \mathrm{U} / \mathrm{g}$ on dry mass basis at $1 \%$ olive oil. Mladenoska and Dimitrovski (57) reported maximum lipolytic activity of $0.28 \mathrm{U} /$ $\mathrm{mL}$ in Geotrichum candidum M2 with sunflower oil.

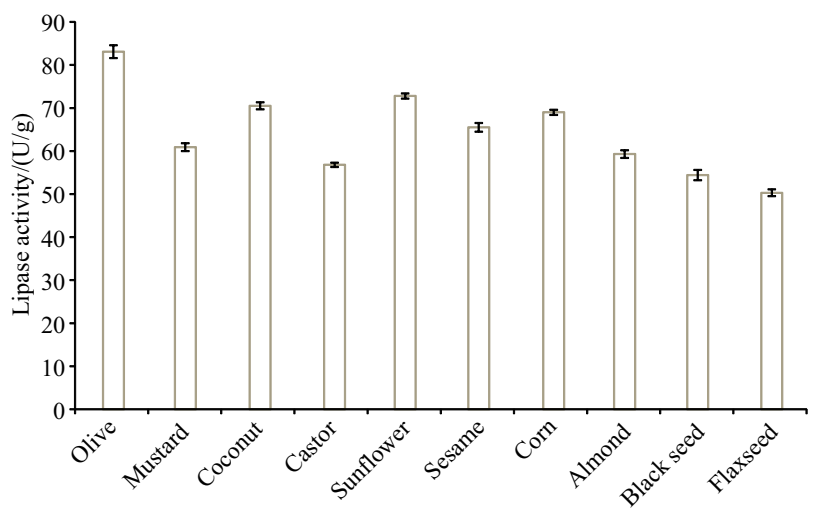

Fig. 4. Effect of different oil sources on lipase production (on dry mass basis) by Curvularia sp. DHE 5 in solid-state fermentation (SSF) 
The influence of olive oil volume fraction on the production of lipase was evaluated. The highest enzyme yield of $(83.4 \pm 2.2) \mathrm{U} / \mathrm{g}$ was reported at $2 \%$ olive oil (data not shown), while at higher volume fractions a decrease in lipase production was observed, which could be correlated with its effect on aeration rate of the culture that might modify the microbial metabolism and promote a delay in mycelium growth and lipase production as reported by Rao et al. (58). This result is consistent with that reported by Rajendran et al. (59) for lipase production by Candida rugosa. Teng and Xu (60) also reported optimum lipase production by $R$. chinensis at $2.3 \%$ olive oil.

\section{Effect of various metal ions}

Metal ions are the important minor nutrients in the medium for cell mass formation and act as cofactor for several biosynthetic enzymes. In the present investigation, several mineral ion sources were incorporated individually in the optimised medium to determine their effect on lipase production by Curvularia sp. DHE 5. The obtained results clearly indicated that lipase production was slightly enhanced by $\mathrm{KCl}((88.9 \pm 1.2) \mathrm{U} / \mathrm{g})$ followed by $\mathrm{MgCl}_{2} \cdot 6 \mathrm{H}_{2} \mathrm{O}(83.6 \pm 0.9)$ and $\mathrm{CaCl}_{2} \cdot 2 \mathrm{H}_{2} \mathrm{O}((82 \pm 1.3) \mathrm{U} / \mathrm{g})$, while the lowest enzyme production was observed with $\mathrm{BaCl}_{2} \cdot 2 \mathrm{H}_{2} \mathrm{O}$ and $\mathrm{CoCl}_{2} \cdot 2 \mathrm{H}_{2} \mathrm{O}$ (Fig. 5). Similarly, Açikel et al. (61) reported the enhancement of lipase production by $R$. delemar in the presence of metal ions $\mathrm{Na}^{+}, \mathrm{K}^{+}, \mathrm{Ca}^{2+}$ and $\mathrm{Mg}^{2+}$ by 1.9-, 1.85-, 1.83- and 1.76-fold, respectively. In addition, the production of extracellular lipase from Aspergillus terreus was also improved in the presence of $\mathrm{Ca}^{2+}$ and $\mathrm{Mg}^{2+}$ ions in the growth medium (62).

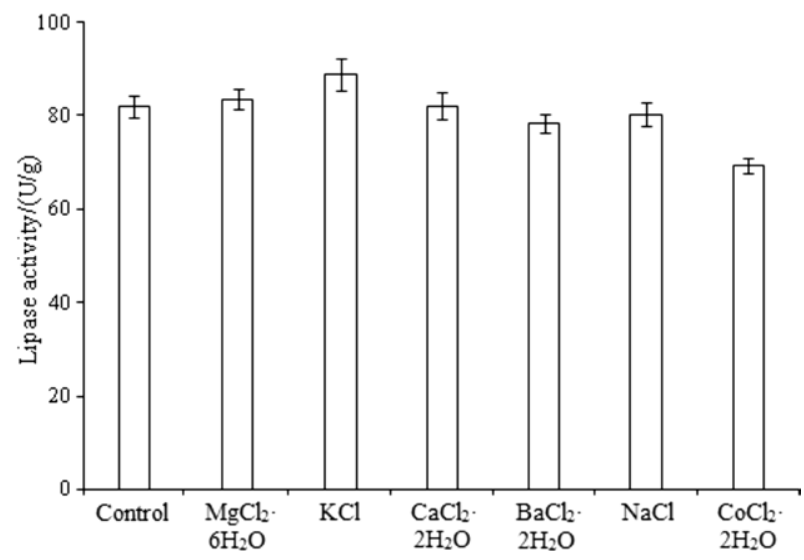

Fig. 5. Effect of various metal ions $(\gamma=50 \mathrm{mg} / \mathrm{L})$ on lipase production (on dry mass basis) by Curvularia sp. DHE 5 in solid-state fermentation (SSF)

\section{Partial purification and characterisation of alkaline lipase}

In the present study, four fractions were obtained by stepwise addition of ammonium sulphate using four mass per volume ratios, namely 20, 40, 60 and $80 \%$. Results in Table 3 clearly demonstrated that the purification of alkaline lipase from Curvularia sp. DHE 5 through ammonium sulfate precipitation (stepwise precipitation between $20-40 \%$ ) and dialysis resulted in 3.1-fold purification with $50.6 \%$ recovery. Besides, the total protein mass decreased from $(1858 \pm 43)$ to $(309 \pm 31) \mathrm{mg}$, while the specific activity was improved from 8.1 to $24.7 \mathrm{U} / \mathrm{mg}$. Other fractions showed lower specific activities and purification folds, which indicates that more foreign proteins are associated with these fractions.

Optimal $\mathrm{pH}$ and $\mathrm{pH}$ stability of the partially purified lipase

In the current study, optimum $\mathrm{pH}$ for lipase activity was evaluated and the highest enzyme activity was reported at $\mathrm{pH}=8$ using Tris- $\mathrm{HCl}$ buffer $(0.1 \mathrm{M})$, as shown in Table 4 . Results revealed that the partially purified enzyme could retain more than $90 \%$ of its initial activity in the $\mathrm{pH}$ range from 6 to 9 , while a reduction in the enzyme activity was detected at $\mathrm{pH}$ higher or lower than the optimum. This inhibitory effect might be attributed to the fact that the enzyme is proteinic in nature and hence any vari-

Table 4. Optimum $\mathrm{pH}$ of partially purified lipase produced by Curvularia sp. DHE 5

\begin{tabular}{lcc}
\hline Buffer $(c=0.1 \mathrm{M})$ & $\mathrm{pH}$ value & Lipase activity/(U/mL) \\
\hline \multirow{3}{*}{ KCl-HCl } & 2.0 & $11.1 \pm 0.2$ \\
& 2.5 & $12.8 \pm 0.2$ \\
& 3.0 & $16.9 \pm 0.3$ \\
\hline Citrate-phosphate & 3.0 & $11.8 \pm 0.2$ \\
& 4.0 & $14.1 \pm 0.2$ \\
& 5.0 & $17.8 \pm 0.3$ \\
Phosphate & 6.0 & $27.1 \pm 0.9$ \\
& 6.0 & $40.5 \pm 1.2$ \\
& 7.0 & $98.9 \pm 2.5$ \\
Tris-HCl & 8.0 & $143.1 \pm 3.1$ \\
& 7.0 & $114.0 \pm 1.8$ \\
& 8.0 & $161.0 \pm 2.4$ \\
Carbonate-bicarbonate & 9.5 & $153.1 \pm 2.8$ \\
& 10.0 & $114.2 \pm 1.8$ \\
\hline
\end{tabular}

Data are expressed as mean value $\pm S$.D. of triplicate measurements

Table 3. Partial purification of extracellular alkaline lipase produced by Curvularia sp. DHE 5

\begin{tabular}{|c|c|c|c|c|c|}
\hline Purification step & $\frac{\text { Total activity }}{U}$ & $\frac{m \text { (total protein })}{\mathrm{mg}}$ & $\frac{\text { Specific activity }}{\mathrm{U} / \mathrm{mg}}$ & $\frac{\text { Purification }}{\text { fold }}$ & $\frac{\text { Recovery }}{\%}$ \\
\hline Culture filtrate & $15083 \pm 117$ & $1858 \pm 43$ & 8.1 & 1.0 & 100 \\
\hline $\begin{array}{l}\text { Ammonium sulphate } \\
\text { precipitation (20-40 \%) }\end{array}$ & $8025+129$ & $354 \pm 29$ & 22.7 & 2.8 & 53.2 \\
\hline Dialysis & $7627 \pm 112$ & $309 \pm 31$ & 24.7 & 3.1 & 50.6 \\
\hline
\end{tabular}


ation in the $\mathrm{pH}$ value can profoundly affect ionic character of its amino or carboxylic groups, affecting the conformation of the enzyme. In addition, the affinity between the enzyme and its substrate might be affected by the $\mathrm{pH}$ of the reaction. Similarly, Sharma et al. (63) reported the same result for the activity of lipase purified from Bacillus sp.

The $\mathrm{pH}$ stability profile showed that the activity of the partially purified enzyme was highly stable at alkaline $\mathrm{pH}$ values. The enzyme retained more than $90 \%$ of its initial activity when incubated at $\mathrm{pH}$ values from 7 to 9 and about $73 \%$ at $\mathrm{pH}=11$ (Table 5). The lower stability of the enzyme at higher or lower $\mathrm{pH}$ values might be attributed to its denaturation, which leads to its inactivation. Bacillus thermoleovorans lipase was reported to be highly active at higher $\mathrm{pH}$ values and stable in a $\mathrm{pH}$ range from 5 to 11 (64). Similarly, Saxena et al. (65) reported that lipase purified from Aspergillus carneus was stable up to 24 $\mathrm{h}$ at $\mathrm{pH}=8$ to 10 .

Table 5. The $\mathrm{pH}$ stability profile of the partially purified alkaline lipase produced by Curvularia sp. DHE 5

\begin{tabular}{cc}
\hline $\mathrm{pH}$ & Relative activity/\% \\
\hline 3.0 & $55.9 \pm 2.1$ \\
4.0 & $71.4 \pm 2.4$ \\
5.0 & $77.1 \pm 1.8$ \\
6.0 & $91.5 \pm 3.1$ \\
7.0 & 100 \\
7.5 & 100 \\
8.0 & 100 \\
9.0 & $93.6 \pm 2.4$ \\
9.5 & $86.7 \pm 2.6$ \\
10 & $77.3 \pm 1.5$ \\
11 & $72.6 \pm 1.4$ \\
\hline
\end{tabular}

Data are expressed as mean value \pm S.D. of triplicate measurements

\section{Optimum temperature and thermal stability}

Results shown in Fig. 6 clearly revealed that the optimum temperature for enzyme activity was $50{ }^{\circ} \mathrm{C}$, while a

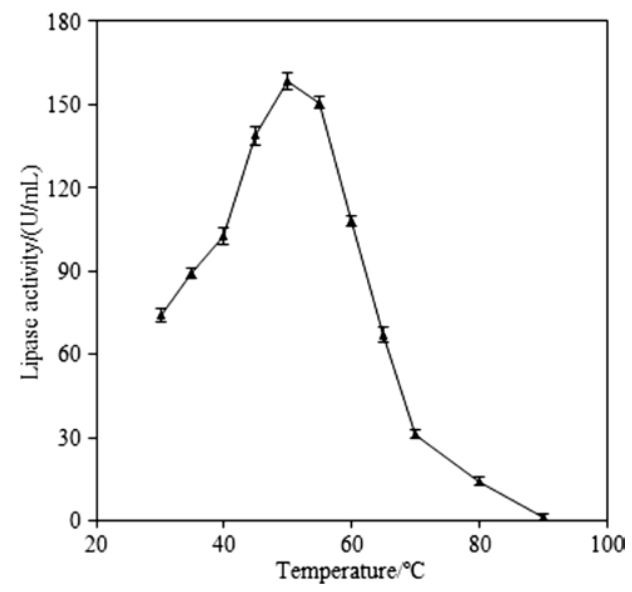

Fig. 6. Temperature optimum of partially purified lipase produced by Curvularia sp. DHE 5 gradual decrease in lipase activity was detected at higher temperatures, which might be attributed to the change in the conformation that causes loss in specificity of the active site (66). This result is in accordance with the findings of Liu et al. (67) for A. niger AN0512 lipase. Lima et al. (68) reported that most of Penicillium lipases exhibited optimum activities at temperatures from 25 to $45^{\circ} \mathrm{C}$, except $P$. aurantiogriseum lipase, which has an optimum activity at $60^{\circ} \mathrm{C}$.

Regarding thermal stability behaviour of the partially purified lipase, no significant loss in enzyme activity was detected when the enzyme was preincubated up to $1 \mathrm{~h}$ at $50{ }^{\circ} \mathrm{C}$. Moreover, the enzyme retained about $63 \%$ of its original activity after $1 \mathrm{~h}$ of incubation at $60{ }^{\circ} \mathrm{C}$ (Fig. 7). These results showed that Curvularia sp. DHE 5 lipase is more stable than the lipase purified from Fusarium oxysporum, which decreased by $50 \%$ at $60{ }^{\circ} \mathrm{C}$ after $60 \mathrm{~min}(69)$. Sethi et al. (70) reported that lipase purified from $A$. terreus retained about $80 \%$ of its original activity after $60 \mathrm{~min}$ at $60{ }^{\circ} \mathrm{C}$.

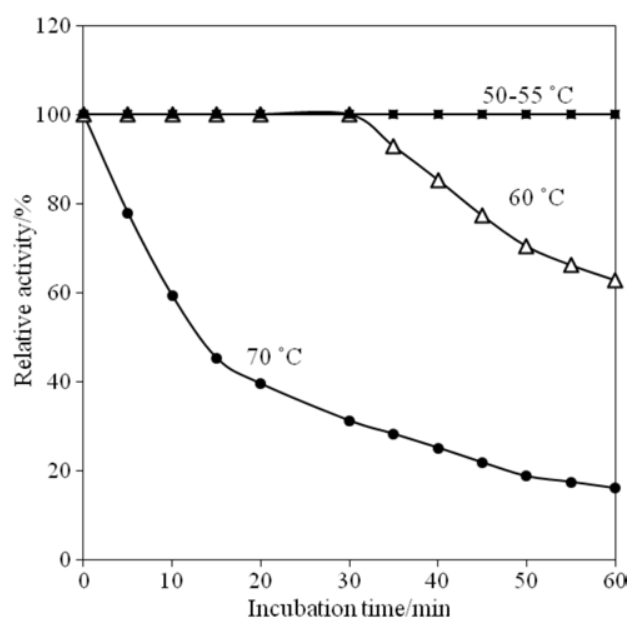

Fig. 7. Thermal stability behaviour of partially purified lipase produced by Curvularia sp. DHE 5

\section{Conclusions}

Thirty fungal isolates were screened for their ability to produce alkaline lipase in solid-state fermentation (SSF). Fungal isolate 25A tentatively identified as Curvularia sp. DHE 5, using $18 \mathrm{~S}$ rRNA analysis, was proven to be the highest lipase producer when using wheat bran as substrate. Furthermore, optimisation of physicochemical parameters led to 7-fold increase in lipase production with maximum lipase production on dry mass basis of $(89 \pm 1.2) \mathrm{U} / \mathrm{g}$ at incubation temperature of $30{ }^{\circ} \mathrm{C}, \mathrm{pH}=7.0$ and $70 \%$ moisture content after seven days of incubation using olive oil ( $2 \%$ ) as an inducer. Optimum temperature and $\mathrm{pH}$ of the partially purified enzyme were reported to be $50{ }^{\circ} \mathrm{C}$ and $\mathrm{pH}=8.0$, respectively, with remarkable thermal and $\mathrm{pH}$ stability.

\section{Acknowledgement}

Authors gratefully acknowledges the National Research Centre (NRC), Cairo, Egypt, for the facilities that enabled the authors to accomplish this work. 


\section{References}

1. Joseph B, Ramteke PW, Thomas G. Cold active microbial lipases: some hot issues and recent developments. Biotechnol Adv. 2008;26:457-70. https://doi.org/10.1016/j.biotechadv.2008.05.003

2. Franken LPG, Marcon NS, Treichel H, Oliveira D, Freire DMG, Dariva C, et al. Effect of treatment with compressed propane on lipases hydrolytic activity. Food Bioprocess Technol. 2010;3:511-20. https://doi.org/10.1007/s11947-008-0087-5

3. Sharma R, Chisti Y, Banerjee UC. Production, purification, characterization and applications of lipases. Biotechnol Adv. 2001;19:627-62. https://doi.org/10.1016/S0734-9750(01)00086-6

4. Maia MMD, Heasley A, Camargo de Morais MM, Melo EHM, Morais Jr. RM, Ledingham WM, Lima Filho JL. Effect of culture conditions on lipase production by Fusarium solani in batch fermentation. Bioresour Technol. 2001;76:23-7. https://doi.org/10.1016/S0960-8524(00)00079-1

5. ul-Haq I, Idrees S, Rajoka MI. Production of lipases by Rhizopus oligosporus by solid-state fermentation. Process Biochem. 2002;37:637-41. https://doi.org/10.1016/S0032-9592(01)00252-7

6. Ülker S, Özel A, Çolak A, Alpay Karaoğlu Ş. Isolation, production and characterization of an extracellular lipase from Trichoderma harzianum isolated from soil. Turk J Biol. 2011; 35:543-50. https://doi.org/10.3906/biy-1004-107

7. Ito T, Kikuta $\mathrm{H}$, Nagamori E, Honda $\mathrm{H}$, Ogino $\mathrm{H}$, Ishikawa $\mathrm{H}$, Kobayashi T. Lipase production in two-step fed-batch culture of organic solvent-tolerant Pseudomonas aeruginosa LST-03. J Biosci Bioeng. 2001;91:245-50. https://doi.org/10.1016/S1389-1723(01)80128-6

8. Rathi P, Goswami VK, Sahai V, Gupta R. Statistical medium optimization and production of a hyper thermostable lipase from Burkholderia cepacia in a bioreactor. J Appl Microbiol. 2002;93:930-6. https://doi.org/10.1046/j.1365-2672.2002.01780.x

9. Singh M, Kakkar K. Enhanced lipase production by solid state fermentation using mustard oil cake as substrate. IJHGMBMS. 2012;1:16-23.

10. Raimbault M. General and microbiological aspects of solid substrate fermentation. Electronic J Biotechnol. 1998;1:17488.

https://doi.org/10.2225/vol1-issue3-fulltext-9

11. Gomori G. Preparations of buffers for use in enzyme studies. Method Enzymol. 1955;1:138-46. https://doi.org/10.1016/0076-6879(55)01020-3

12. Ishaq $\mathrm{F}$, Khan A. Isolation, identification and comparative study of fungal and bacterial strains found in organic and inorganic soils of different agricultural fields. Recent Res Sci Technol. 2011;3:30-6.

13. Ellis MB, Ellis JP. Microfungi on land plants: an identification handbook. New York, NY, USA: Macmillan Publishing Co.; 1985. p.324.

14. Benson DA, Karsch-Mizrachi I, Lipman DJ, Wheeler DL. GenBank. Nucleic Acids Res. 2008;36:D25-30. https://doi.org/10.1093/nar/gkm929

15. Altschul SF, Madden TL, Schäffer AA, Zhang J, Zhang Z, Miller W, Lipman DJ. Gapped BLAST and PSI-BLAST: a new generation of protein database search programs. Nucleic Acids Res. 1997;25:3389-402. https://doi.org/10.1093/nar/25.17.3389

16. Tamura K, Dudley J, Nei M, Kumar S. MEGA4: molecular evolutionary genetics analysis (MEGA) software version 4.0. Mol Biol Evol. 2007;24:1596-99.

https://doi.org/10.1093/molbev/msm092
17. AOAC Official Method 971.24: Aflatoxins in coconut, copra, and copra meal. Rockville, MD, USA: AOAC International; 2000.

18. Deabes MM, Darwish HR, Abdel-Aziz KB, Farag IM, Nada SA, Tawfek NS. Protective effects of Lactobacillus rhamnosus GG on aflatoxins-induced toxicities in male albino mice. J Environment Analytic Toxicol. 2012;2:132. https://doi.org/10.4172/2161-0525.1000132

19. Glickman SE, Kilburn JO, Butler WR, Ramos LS. Rapid identification of mycolic acid patterns of mycobacteria by highperformance liquid chromatography using pattern recognition software and a Mycobacterium library. J Clin Microbiol. 1994;740-45.

20. Nath M, Hindumathy CK. Isolation, optimization and purification of lipase from Myroides odoratimimus. IJLRST. 2012;1:239-46.

21. Pera LM, Romero CM, Baigori MD, Castro GR. Catalytic properties of lipase extracts from Aspergillus niger. Food Technol Biotechnol. 2006;44:247-52.

22. Bradford MM. A rapid and sensitive method for the quantitation of microgram quantities of protein utilizing the principle of protein-dye binding. Anal Biochem. 1976;72:248-54. https://doi.org/10.1016/0003-2697(76)90527-3

23. Lin ES, Wang CC, Sung SC. Cultivating conditions influence lipase production by the edible basidiomycete Antrodia cinnamomea in submerged culture. Enzyme Microb Technol. 2006;39:98-102.

https://doi.org/10.1016/j.enzmictec.2005.10.002

24. Sarkar S, Sreekanth B, Kan S, Banerjee R, Bhattacharyya BC. Production and optimization of microbial lipase. Bioprocess Eng. 1998;19:29-32.

https://doi.org/10.1007/s004490050478

25. Rodriguez JA, Mateos JC, Nungaray J, González V, Bhagnagar $\mathrm{T}$, Roussos $\mathrm{S}$, et al. Improving lipase production by nutrient source modification using Rhizopus homothallicus cultured in solid state fermentation. Process Biochem. 2006;11: 2264-9. https://doi.org/10.1016/j.procbio.2006.05.017

26. Cihangir N, Sarikaya E. Investigation of lipase production by a new isolate of Aspergillus sp. World J Microbiol Biotechnol. 2004;20:193-7.

https://doi.org/10.1023/B:WIBI.0000021781.61031.3a

27. Kaushik R, Saran S, Isar J, Saxena RK. Statistical optimization of medium components and growth conditions by response surface methodology to enhance lipase production by Aspergillus carneus. J Mol Catal B Enzym. 2006;40:121-6. https://doi.org/10.1016/j.molcatb.2006.02.019

28. Kempka AP, Lipke NL, Pinheiro TLF, Menoncin S, Treichel $\mathrm{H}$, Freire DMG, et al. Response surface method to optimize the production and characterization of lipase from Penicillium verrucosum in solid-state fermentation. Bioprocess Biosyst Eng. 2008;31:119-25. https://doi.org/10.1007/s00449-007-0154-8

29. Vargas GDLP, Treichel H, de Oliveira D, Beneti SC, Freire DMG, Di Luccio M. Optimization of lipase production by Penicillium simplicissimum in soybean meal. J Chem Technol Biotechnol. 2008;83:47-54. https://doi.org/10.1002/jctb.1776

30. Mateos-Díaz JC, Rodriguez JA, Roussos S, Cordova J, Abousalham A, Carriere F, Baratti J. Lipase from the thermotolerant fungus Rhizopus homothallicus is more thermostable when produced using solid state fermentation than liquid fermentation procedures. Enzyme Microb Technol. 2006; 39:1042-50.

https://doi.org/10.1016/j.enzmictec.2006.02.005

31. de Azeredo LAI, Gomes PM, Sant'Anna Jr. GL, Castilho LR, Freire DMG. Production and regulation of lipase activity from Penicillium restrictum in submerged and solid-state 
fermentations. Curr Microbiol. 2007;54:361-5.

https://doi.org/10.1007/s00284-006-0425-7

32. Contesini FJ, Lopes DB, Macedo GA, Nascimento MG, Carvalho PO. Aspergillus sp. lipase: Potential biocatalyst for industrial use. J Mol Catal B Enzym. 2010;67:163-71. https://doi.org/10.1016/j.molcatb.2010.07.021

33. Mahadik ND, Puntambekar US, Bastawde KB, Khire JM, Gokhale DV. Production of acidic lipase by Aspergillus niger in solid state fermentation. Process Biochem. 2002;38:715-21. https://doi.org/10.1016/S0032-9592(02)00194-2

34. Lequart C, Nuzillard JM, Kurek B, Debeire P. Hydrolysis of wheat bran and straw by an endoxylanase: production and structural characterization of cinnamoyl-oligosaccharides. Carbohydr Res. 1999;319:102-11. https://doi.org/10.1016/S0008-6215(99)00110-X

35. Mahanta N, Gupta A, Khare SK. Production of protease and lipase by solvent tolerant Pseudomonas aeruginosa PseA in solid state fermentation using Jatropha curcas seed cake as substrate. Bioresour Technol. 2008;99:1729-35. https://doi.org/10.1016/j.biortech.2007.03.046

36. Rajan A, Nair AJ. A comparative study on alkaline lipase production by a newly isolated Aspergillus fumigatus MTCC 9657 in submerged and solid-state fermentation using economically and industrially feasible substrate. Turk J Biol. 2011;35:569-74.

https://doi.org/10.3906/biy-0912-6

37. Kamini NR, Mala JGS, Puvanakrishnan R. Lipase production from Aspergillus niger by solid-state fermentation using gingelly oil cake. Process Biochem. 1998;33:505-11. https://doi.org/10.1016/S0032-9592(98)00005-3

38. Gutarra MLE, Godoy MG, Maugeri F, Rodigues MI, Freire DMG, Castilho LR. Production of an acidic and thermostable lipase of the mesophilic fungus Penicillium simplicissimum by solid state fermentation. Bioresour Technol. 2009;21:524954 .

https://doi.org/10.1016/j.biortech.2008.08.050

39. Moreira KA, Albuquerque BF, Teixeira MFS, Porto ALF, Lima Filho JL. Application of protease from Nocardiopsis sp. as a laundry detergent additive. World J Microbiol Biotechnol. 2002;18:307-12. https://doi.org/10.1023/A:1015221327263

40. Rehman S, Bhatti HN, Bhatti IA, Asgher M. Optimization of process parameters for enhanced production of lipase by Penicillium notatum using agricultural wastes. Afr J Biotechnol. 2011;10:19580-9. https://doi.org/10.5897/AJB11.1082

41. Zhang JW, Zeng RY. Molecular cloning and expression of a cold-adapted lipase gene from an Antarctic deep sea psychrotrophic bacterium Pseudomonas sp. 7323. Mar Biotechnol. 2008;10:612-21. https://doi.org/10.1007/s10126-008-9099-4

42. Yang FC, Ke YF, Kuo SS. Effect of fatty acids on the mycelial growth and polysaccharide formation by Ganoderma lucidum in shake flask cultures. Enzyme Microb Technol. 2000;27:295-301. https://doi.org/10.1016/S0141-0229(00)00213-1

43. Balaji V, Ebenezer P. Optimization of extracellular lipase production in Colletotrichum gloeosporioides by solid state fermentation. Ind J Sci Technol. 2008;1:1-8.

44. Sun SY, Xu Y. Solid-state for 'whole-cell synthetic lipase' production from Rhizopus chinesis and identification of the functional enzyme. Process Biochem. 2008;43:219-24. https://doi.org/10.1016/j.procbio.2007.11.010

45. Toscano L, Montero G, Stoytcheva M, Cervantes L, Gochev V. Comparison of the performances of four hydrophilic polymers as supports for lipase immobilization. Biotechnol Biotechnol Equip. 2014;28:52-60. https://doi.org/10.1080/13102818.2014.901684
46. Maia MMD, Camargo de Morais MM, de Morais Jr. MA, Melo EHM, de Lima Filho JL. Production of extracellular lipase by the phytopathogenic fungus Fusarium solani FS1. Rev Microbiol. 1999;30:304-9. https://doi.org/10.1590/S0001-37141999000400003

47. Imandi SB, Karanam SK, Garapati HR. Optimization of media constituents for the production of lipase in solid state fermentation by Yarrowia lipolytica from palm Kernal cake (Elaeis guineensis). Adv Biosci Biotechnol. 2010;1:115-21. https://doi.org/10.4236/abb.2010.12016

48. Amin M, Bhatti HN, Zuber M, Bhatti IA, Asgher M. Potential use of agricultural wastes for the production of lipase by Aspergillus melleus under solid state fermentation. J Anim Plant Sci. 2014;24:1430-7.

49. Ramachandran S, Patel AK, Nampoothiri KM, Francis F, Nagy V, Szakacs P, Pandey A. Coconut oil cake - a potential material for production of $\alpha$-amylase. Bioresour Technol. 2004;93:169-74. https://doi.org/10.1016/j.biortech.2003.10.021

50. Kumar S, Katiyar N, Ingle P, Negi S. Use of evolutionary operation (EVOP) factorial design technique to develop a bioprocess using grease waste as a substrate for lipase production. Bioresour Technol. 2011;102:4909-12. https://doi.org/10.1016/j.biortech.2010.12.114

51. Sethi BK, Rout JR, Das R, Nanda PK, Sahoo SL. Lipase production by Aspergillus terreus using mustard seed oil cake as a carbon source. Ann Microbiol. 2013;63:241-52. https://doi.org/10.1007/s13213-012-0467-y

52. Wang D, Xu Y, Shan T. Effects of oils and oil-related substrates on the synthetic activity of membrane-bound lipase from Rhizopus chinensis and optimization of the lipase fermentation media. Biochem Eng J. 2008;40:30-7. https://doi.org/10.1016/j.bej.2008.03.003

53. Iwai M, Tsujisaka Y. Fungal lipase. In: Borgstrom B, Brockman HL, editors. Lipases. Amsterdam, Netherlands: Elsevier; 1984. pp.443-69.

54. Ohnishi K, Yoshida Y, Toita J, Sekiguchi J. Purification and characterization of a novel lipolytic enzyme from Aspergillus oryzae. J Ferment Bioeng. 1994;78:413-9. https://doi.org/10.1016/0922-338X(94)90039-6

55. Ferreira Costa MA, Peralta RM. Production of lipase by soil fungi and partial characterization of lipase from a selected strain Penicillium wortmanii. J Basic Microbiol. 1999;39:11-5. https://doi.org/10.1002/(SICI)1521-4028(199903)39:1<11: :AID-JOBM11>3.0.CO;2-8

56. Adinarayana K, Bapi Raju KVVSN, Zargar MI, Devi RB, Lakshmi PJ, Elliah P. Optimization of process parameters for production of lipase in solid state fermentation by newly isolated Aspergillus sp. Indian J Biotechnol. 2004;3:65-9.

57. Mladenoska I, Dimitrovski A. Lipase production by Geotrichum candidum- M2. Bull Chem Technol Macedonia. 2001; 20:39-43.

58. Rao PV, Jayaraman K, Lakshmanan CM. Production of lipase by Candida rugosa in solid state fermentation. 1: determenation of significant variables. Process Biochem. 1993;28:385-9. https://doi.org/10.1016/0032-9592(93)80025-C

59. Rajendran A, Palanisamy A, Thangavelu V. Evaluation of medium components by Plackett-Burman statistical design for lipase production by Candida rugosa and kinetic modeling. Chin J Biotechnol. 2008;24:436-44. https://doi.org/10.1016/S1872-2075(08)60024-2

60. Teng Y, Xu Y. Culture condition improvement for whole-cell lipase production in submerged fermentation by Rhizopus chinensis using statistical method. Bioresour Technol. 2008;99:3900-7. https://doi.org/10.1016/j.biortech.2007.07.057 
61. Açikel Ü, Erşan M, Sag Açikel Y. The effects of the composition of growth medium and fermentation conditions on the production of lipase by R. delemar. Turk J Biol. 2011;35:3544. https://doi.org/10.3906/biy-0902-14

62. Gulati R, Saxena RK, Gupta R, Yadav RP, Davidson WS. Parametric optimization of Aspergillus terreus lipase production and its potential in ester synthesis. Process Biochem. 1999;35:459-64. https://doi.org/10.1016/S0032-9592(99)00090-4

63. Sharma R, Soni SK, Vohra RM, Gupta LK, Gupta JK. Purification and characterization of a thermostable alkaline lipase from a new thermophilic Bacillus sp. RSJ-1. Process Biochem. 2002;37:1075-84. https://doi.org/10.1016/S0032-9592(01)00316-8

64. Castro-Ochoa LD, Rodríguez-Gómez C, Valerio-Alfaro G, Oliart Ros R. Screening, purification and characterization of the thermoalkalophilic lipase produced by Bacillus thermoleovorans CCR11. Enzyme Microb Technol. 2005;37:648-54. https://doi.org/10.1016/j.enzmictec.2005.06.003

65. Saxena RK, Davidson WS, Sheoran A, Giri B. Purification and characterization of an alkaline thermostable lipase from Aspergillus carneus. Process Biochem. 2003;39:239-47. https://doi.org/10.1016/S0032-9592(03)00068-2
66. Curvelo Santana JC, Araújo SA, Librantz AFH, Tambourgi EB. Optimization of corn malt drying by use of a genetic algorithm. Dry Technol. 2010;28:1236-44. https://doi.org/10.1080/07373937.2010.500439

67. Liu G, Hu S, Li L, Hou Y. Purification and characterization of a lipase with high thermostability and polar organic solvent-tolerance from Aspergillus niger AN0512. Lipids. 2015;50: 1155-63. https://doi.org/10.1007/s11745-015-4052-6

68. Lima VMG, Krieger N, Sarquis MIM, Mitchell DA, Ramos LP, Fontana JD. Effect of nitrogen and carbon sources on lipase production by Penicillium aurantiogriseum. Food Technol Biotechnol. 2003;41:105-10.

69. Hoshino T, Sasaki T, Watanabe Y, Nagasawa T, Yamane T. Purification and some characteristics of extracellular lipase from Fusarium oxysporum f. sp. lini. Biosci Biotechnol Biochem. 1992;56:660-4. https://doi.org/10.1271/bbb.56.660

70. Sethi BK, Nanda PK, Sahoo S. Characterization of biotechnologically relevant extracellular lipase produced by Aspergillus terreus NCFT 4269.10. Braz J Microbiol. 2016;47:143-9. https://doi.org/10.1016/j.bjm.2015.11.026 